\title{
IS THERE VALUE IN KEEPING A PROMISE?
}

\author{
A RESPONSE TO JOSEPH RAZ
}

\section{Crescente Molina}

$\square$ OME PHILOSOPHERS explain the demands for performance that promises impose on promisors by affirming that the fact of making a promise to $\phi$ constitutes or creates a reason for $\phi$-ing. That means that this fact-making a valid promise - recommends or demands $\phi$-ing because there is value in someone's $\phi$-ing if she has promised to do so. This view has famously been defended by Joseph Raz. ${ }^{1}$ According to Raz, the fact of making a promise constitutes for the promisor both a reason to perform the promised act and a reason for not acting for at least some of the reasons that recommend something different than acting as promised (an "exclusionary" reason). On this view, if I promise to water your plants tomorrow I have both a reason to water your plants tomorrow and a reason for not acting for at least some of the considerations that recommend something different than watering your plants tomorrow (e.g., that my plants need more care than yours and it would be better if I use my time tomorrow for taking care of my plants rather than yours). Moreover, under this model, the reason to keep our promises is also a content-independent reason. ${ }^{2}$ Leaving aside exceptional cases, we have a reason to perform our promises regardless of what the content of the promise is. If I promise to water your plants, I have a reason for watering your plants and for not acting for some of the reasons that militate against watering your plants, but it is the sole fact of this act (watering your plants) being promised that gives me those reasons and not other features or properties of it. As Raz does, I will call the content-independent reason to keep our promises a "promissory reason." 3 I will argue that Raz's account of the grounds of promissory reasons has some serious difficulties.

1 Raz, "Promises and Obligations," 218-19, and “Is There a Reason to Keep a Promise?” 58. Arguably a similar position has been defended by Watson, "Promises, Reasons, and Normative Powers," 155 .

2 Raz, "Is There a Reason to Keep a Promise?" 59-63.

3 Raz, "Is There a Reason to Keep a Promise?" 59. 


\section{THE GROUNDS OF PROMISSORY REASONS}

Different kinds of reasons demand that we keep our promises. For example, if I promise my best friend that I will go to her house for dinner on New Year's Eve, I have a reason to perform if I know that she will be disappointed if I do not show up, or if she prepared food for me that will be wasted if I do not show up, or even maybe simply because I enjoy being with her and it would be fun to go. All these reasons largely derive from the context in which the promise takes place, from the nature of the relationship between the promisor and the promisee, from the expectations created by the promise in the promisee, etc. Failing to keep a promise could imply nonconformity with all these different sorts of reasons. However, these reasons are not promissory reasons. As I previously defined them, promissory reasons are reasons to perform the promised act and to exclude some of the reasons that recommend otherwise that promises generate qua promises. But if promissory reasons obtain in virtue of facts that are not given by the nature of the promised act nor from all the different facts that may surround the making and performing of a promise (e.g., that the promisee or promisor will benefit from the performance), in virtue of which fact do we have a promissory reason?

According to some writers, the reason to keep our promises is grounded in a social practice of promise making and keeping. On this view (the "Practice View"), the practice of promising is a social rule by which-provided the requirements of the rule are fulfilled (e.g., that the promise was not given under duress) - promisors are obliged to perform the action they communicated to their promisee that they will perform. Writers like David Hume and John Rawls maintained that the rule of promising is valuable because it facilitates coordination, and since the possibility of coordination generated by the rule is realized only if a sufficient number of promisors perform their promises, the rule gives promisors a practice-based reason to keep their promises. ${ }^{4}$ Against the Practice View, T.M. Scanlon has argued that we do not need something like the social practice of promising for us to be able to undertake promissory obligations. Scanlon holds that there is a general principle (the "principle of fidelity") that demands that, in the absence of justification, an agent who, with the aim of providing assurance to another person, voluntarily and intentionally causes that person to expect that he will perform or omit a certain action, and this person wants to be assured of this (and both parties know about the other's relevant beliefs and intentions), he should act as he said he would unless the other person consents otherwise. Making a promise activates this general principle of fidelity, 
giving the promisor a reason to keep his promise. ${ }^{5}$ Despite their deficiencies, the Practice View and Scanlon's account find a way of explaining why promises impose demands for performance on us. ${ }^{6}$ They maintain that making a promise just triggers or activates normative reasons that, before making a promise, we had in a conditional form (i.e., reasons to protect and maintain valuable practices and reasons to avoid disappointing the expectations we cause in others).

Raz, on the other hand, refuses to adopt something like the Practice View or Scanlon's account, but nevertheless insists that the fact of making a valid promise creates or establishes a promissory reason.

\section{RAZ ON PROMISSORY REASONS}

Raz acknowledges that the fact that grounds promissory reason cannot be an interest or benefit of the promisee derived from the content of the promise itself, since, as we know, whether the promisee benefits from the performance of the promised act or not is a contingent matter that does not determine promises' bindingness. ${ }^{7}$ In his early work on promises, Raz maintains that the ground for the promissory reason does not reside in some property of the promised act, but in the same fact or interest that justifies our power to make promises. In this early account, Raz maintains that what justifies our power to promise is our interest in creating and developing special bonds with other people. ${ }^{8}$ Raz argues that the relationship between the content-independent reason to perform a specific promise (the promissory reason) and the reason or value that justifies our power to promise is a relation of practical inference. ${ }^{9}$ Thus, if I promised to $\phi$, the proposition "I have a reason to $\phi$ because I have promised to" is just the normative conclusion that follows from our interest in developing special bonds with others. However, Raz struggles to account for this conclusion. It is hard to see how our interest in being able to undertake special obligations with others gives us sufficient ground for affirming the existence of a promissory reason, that is, a content-independent reason to keep our promises. There may be value in

5 Scanlon, What We Owe to Each Other, 304.

6 For criticism of Scanlon's account, see Kolodny and Wallace, "Promises and Practices Revisited," 139-48; Owens, Shaping the Normative Landscape, ch. 9; Pratt, "Some Features of Promises and Their Obligations," 390-94. For criticism of the Practice View, see, e.g., Shiffrin, "Promising, Intimate Relationships, and Conventionalism," 519-23; Scanlon, What We Owe to Each Other, 309-11; Owens, Shaping the Normative Landscape, ch. 5.

7 Raz, "Promises and Obligations," 213-14.

8 Raz, "Promises and Obligations," 226-28.

9 Raz, "Promises and Obligations," 219. See also Raz, The Morality of Freedom, 84. 
us being able to develop special obligations with others, but from this does not immediately follow that there must be value in us performing those obligations regardless of their content. It seems that we need some further argument to find the link between the consideration that justifies our ability to undertake voluntary obligations and the one that grounds promissory reasons.

In recent work Raz shares these doubts, and now tries to find something in each specific promise that, though different from a mere benefit to the promisee that arises from the content of the promised act, serves as a ground for promissory reasons. ${ }^{10}$ Raz argues that the point of promising is that by making a promise the promisor gives or provides something for the promisee. He argues that in every valid promise what the promisor gives the promisee is the normative assurance that he will perform his promise. According to Raz, this normative assurance gives the promisor a right to performance and the power to waive such a right and release the promisor of his obligation. ${ }^{11}$ However, it is still not very clear to me what Raz means when he affirms that promisors give their promisees the normative assurance of performance. As is clear, this assurance cannot be the, let us call it "epistemic" assurance, that the performance will actually happen. On many occasions promisees have no more reasons to believe that the promised act will take place just because the promisor promised it (the promisor might have a very bad promise-keeping record with the promisee, but his promise is nevertheless binding). Thus, the interest of promisees in each promise cannot be the interest in being more certain that the promised performance will occur.

Raz seems to argue that what the promisee receives from the promisor- that constitutes the content of the normative assurance that promisors provide to their promisees even when they do not benefit from the promised act-is an opportunity to develop interests in the performance. ${ }^{12}$ A promisor, by making a specific promise, gives the promisee the option to develop interests in the performance, and even when the promisee does not benefit from the promise when it was made, he has the opportunity to become interested in the content of the promise, and it is such opportunity that the promisor must respect and protect by performing his promise if required by the promisee. Thus, the promisor has a reason to perform unless the promisee releases him. ${ }^{13}$ But there are problems with this proposal.

Raz characterizes the fact in virtue of which promissory reasons obtain as being something that the promisor gives to the promisee by making the promise,

10 Raz, "Is There a Reason to Keep a Promise?" 67.

11 Raz, "Is There a Reason to Keep a Promise?" 71-72.

12 Raz, "Is There a Reason to Keep a Promise?" 73.

13 Raz, "Is There a Reason to Keep a Promise?" 77. 
namely an opportunity to develop an interest in the performance. However, as I remarked before, what Raz refers to here must be something different than the mere expectations of performance that the promisor could generate in the promisee. So, if Raz's account claims to be something different than, for example, Scanlon's account, he must affirm that the opportunity to develop an interest in the performance the promisor gives to his promisee is generated regardless of whether or not the promisee forms any expectations that the promisor's performance will take place. However, if such an opportunity did exist, even when there are no expectations of performance, how would we characterize it?

One could argue that what the promisor gives to the promisee is authority over the promisor regarding the promised act. That is, the promisor gives to the promisee the power to control the permissibility of the promisor's failing to act as promised (i.e., the promisee acquires the power to cancel the promisor's obligation at will). David Owens defends this view, and maintains that, by making a promise, promisors specifically serve promisees' "authority-interest": that is, an interest in being able to control others' obligations. Promises would paradigmatically serve this interest even if they also served other interests of promisees (e.g., their interest in being able to predict promisors' future behavior). ${ }^{14}$ Raz rejects this view. He states that he doubts the existence of Owens's authority-interest, and does not further engage with Owens's position. ${ }^{15}$

Thus, the problems for Raz's account persist. Until he gives us a clearer idea of what it is for promises to give normative assurance to promisees, and until he explains the sense in which this expands promisees' valuable opportunities, his account of the grounds of promissory reasons remains unconvincing. ${ }^{16}$

University of Oxford crescente.molina@bnc.ox.ac.uk

Owens, Shaping the Normative Landscape, chs. 4-6, and "A Simple Theory of Promising," 67-74.

15 Raz, "Is There a Reason to Keep a Promise?" 74.

16 Many thanks to James Edwards, Raffael Fasel, John Gardner, Manuel González, Felipe Jiménez, Christopher Kutz, Sebastian Lewis, David Owens, Olof Page, Alejandro Saenz, Sandy Steel, Samuel Williams, Tarek Yusari, an anonymous referee for the Journal of Ethics and Social Philosophy, and to the audience at the Oxford Jurisprudence Discussion Group for their helpful comments. 


\section{REFERENCES}

Hume, David. A Treatise on Human Nature. Oxford: Oxford University Press, 2001.

Kolodny, Niko, and R. Jay Wallace. "Promises and Practices Revisited." Philosophy and Public Affairs 31, no. 2 (Spring 2003): 119-54.

Owens, David. Shaping the Normative Landscape. Oxford: Oxford University Press, 2012.

_ . "A Simple Theory of Promising" Philosophical Review 115, no. 1 (January 2006): 51-77.

Pratt, Michael. "Some Features of Promises and Their Obligations." Southern Journal of Philosophy 52, no. 3 (September 2014): 382-402.

Rawls, John. A Theory of Justice. Cambridge, MA: Harvard University Press, 1999. Raz, Joseph. "Is There a Reason to Keep a Promise?” In Philosophical Foundations of Contract Law, edited by Gregory Klass, George Letsas, and Prince Saprai, 58-77. Oxford: Oxford University Press, 2014.

- The Morality of Freedom. Oxford: Oxford University Press, 2009. . "Promises and Obligations." In Law, Morality, and Society, edited by P.M.S. Hacker and Joseph Raz, 210-28. Oxford: Oxford University Press, 1977.

Scanlon, T.M. What We Owe to Each Other. Cambridge, MA: Harvard University Press, 2000.

Shiffrin, Seana V. "Promising, Intimate Relationships, and Conventionalism." Philosophical Review 117, no. 4 (October 2008): 481-524.

Watson, Gary. "Promises, Reasons, and Normative Powers." In Reasons for Action, edited by David Sobel and Steven Wall, 155-78. Cambridge: Cambridge University Press, 2011. 